\title{
CARTOGRAFIAS DO COSMOS: CONHECIMENTO, ICONOGRAFIA E ARTES VERBAIS ENTRE OS MARUBO*
}

Pedro de Niemeyer Cesarino

\section{Apresentação}

Quando iniciei meu trabalho entre os Marubo (falantes de língua da família Pano do rio Ituí, Vale do Javari, Amazonas), eu já havia tomado contato com alguns desenhos recolhidos por Delvair Montagner (1996) nas décadas de 1970 e 80. Os exemplares publicados pela antropóloga sugeriam uma iconografia rigorosa, dotada de estilo, repertório e regras de composição específicas. Decidi então estimular sua produção local. Tratei, no início, de fazer com que distintos segmentos da sociedade desenhassem: crianças, jovens, mulheres, homens maduros e idosos. Via de regra, eu recebia das mulheres diversas transposições para o papel dos padrões gráficos kene e, dos homens, desenhos de árvores, animais e mapas das aldeias. Ninguém se sentia habilitado a colocar no papel outros temas além daqueles que, de imediato, tendemos a chamar de naturalistas. A exceção ficava por conta de três xamãs mais velhos que, de pronto, se empenharam em criar desenhos diversificados nos blocos de canson que eu lhes fornecia. Passei a me concentrar no trabalho com eles, bem como nas mulheres especialistas nos padrões kene. Estas últimas expressões, que costumam ser aplicadas sobre os corpos e diversos artefatos, não serão estudadas aqui. ${ }^{1}$

O material discutido neste artigo se refere a um movimento específico da produção realizada pelos xamãs, que acumula cerca de 200 exemplares. Trata-se daquele no qual estruturas narrativas e cosmográficas se encontram transpostas para o papel, a partir de sua articulação com o arcabouço de fórmulas poéticas e com a disposição geral da memória envolvida nos processos de transmissão dos conhecimentos xamanísticos. ${ }^{2}$ Como compreender a consolidação súbita de uma iconografia relacionada ao xamanismo e à mitologia de um povo amazônico? Que relações ela estabelece com as suas artes verbais? Que regime de memória está envolvido nos seus processos de transmissão? Como veremos aqui, os xamãs (cantadores e desenhistas), 
talvez à sua própria revelia, atualizam configurações prévias de pensamento em suas produções, cuja compreensão demanda um ajuste de nossas categorias analíticas.

Para que possamos nos aproximar do modo de conhecimento envolvido nessa imbricação entre o verbal e o visual, faz-se necessário abandonar a nossa projeção de um corte rígido entre determinada expressão "naturalista" e outra voltada a temas cosmológicos. Na realidade, se existe alguma separação em tal repertório, ela deve ser compreendida a partir das distribuições de autoridade do conhecimento entre os Marubo. Os homens comuns não se sentiam autorizados para colocar no papel determinados saberes relacionados ao xamanismo e à mitologia, como se o papel constituísse uma forma fixa de representação passível de ser desautorizada por alguém mais qualificado; como se estivessem, desta maneira, circunscrevendo as suas expressões àquele domínio de conhecimento que lhes competia. Deixavam, assim, o tratamento de temas relacionados às narrativas míticas e à cosmologia ao encargo dos xamãs e se dedicavam a desenhar, sobretudo, mapas das aldeias, árvores e remédios do mato.

De modo surpreendente, o material que vinha à tona pelas mãos dos xamãs apresentava, por sua vez, uma complexidade e uma constância próprias, que indicavam cada vez mais a existência de uma iconografia expressiva entre os Marubo do alto Ituí (ainda mais quando somado àquelas produções recolhidas nas décadas anteriores por Montagner). E isso não apenas por conta de um critério quantitativo ou temporal, mas também pela constância formal e temática dos desenhos que surgiam aos poucos. Não há aqui, entretanto, algo similar ao que existe entre os Walbiri estudados por Nancy Munn (1986 [1973]), ou seja, um conjunto coerente de categorias locais para designar as vertentes distintas de uma produção iconográfica, bem como uma relação direta com a eficácia ritual. Esta associação está restrita aos padrões gráficos kene, mas não aos desenhos em consideração, que são chamados genericamente de yochĩ (o mesmo termo utilizado para designar fotografias, cópias e reproduções visuais diversas) e que, vale notar, não costumam mobilizar tanto interesse dos Marubo para além do contexto de interação com o antropólogo. ${ }^{3}$

Como se não bastasse, a iconografia marubo sugere uma estrutura pictográfica bastante similar a de outros casos ameríndios clássicos, tais como kuna, ojibwa e nahuatl: o próprio leitor perceberá a forte presença de ordem e paralelismo, de organizações em lista, de percursos e configurações espaciais por territórios, de transposições gráficas para nomes de pessoas e lugares, entre outros elementos que indicam convenções determinadas orientadas a partir de um repertório fechado, seletivo, sequencial e com uma relativa persistência temporal, de acordo com os critérios recentemente propostos por Severi (2007). 
Entretanto, como se justificaria a presença de uma pictografia não apenas por conta de seu curto período de existência, mas também pela ausência de um sistema consolidado de comunicação gráfica? Os materiais haviam sido recolhidos em função de um propósito bastante específico: eu desenvolvia uma parceria com o programa de educação escolar de uma organização não governamental (o Centro de Trabalho Indigenista) e, desta forma, propunha aos xamãs a elaboração de desenhos sobre os seus conhecimentos para a confecção de livros para as escolas; desenhos que deveriam, assim, ser examinados pelos jovens, muito frequentemente afastados dos pensamentos veiculados por seus parentes mais velhos. Havia uma intenção pragmática e comunicativa na produção deste repertório que, talvez, tenha orientado a sua disposição pictográfica por meio de uma estrita relação de tradução com o repertório de fórmulas verbais. ${ }^{4}$

No entanto, tal possibilidade não resolve os nossos problemas. O projeto de constituição de livros para escolas não estava presente na pesquisa de Montagner, que recolheu desenhos compostos através de um conjunto similar de unidades visuais. Os desenhos recolhidos por mim foram feitos a partir de signos gráficos praticamente idênticos, adotados por desenhistas isolados uns dos outros durante o período em que foram executados. Não houve qualquer decisão ou convenção prévia em relação aos signos adotados, muito embora as fórmulas verbais sejam, estas sim, largamente partilhadas através de interlocuções diversas que estes mesmos xamãs estabelecem entre si. Como explicar tal convergência de convenções que exibem também, como dizíamos, um forte ar de família com signos diversos adotados em outras pictografias consolidadas (tais como as produzidas pelos Kuna, Ojibwa e pelos falantes de nahuatl) para designar lugares, trajetos, formas de surgimento, topônimos e antropônimos? Não se trata aqui de apresentar respostas definitivas a tais problemas, mas sim de mostrar o seu percurso através de uma investigação do pensamento xamanístico marubo. ${ }^{5}$

\section{Conhecimento e multiplicidade}

Um dos desenhos a serem examinados nas páginas seguintes, batizado por mim de "Os mestres dos animais" (figura 5), pode ser compreendido como uma cartografia do cosmos, ou um cosmograma. Armando Mariano Cherõpapa, o xamã desenhista, dispõe de modo rigorosamente estruturado seis donos ou mestres dos animais (ivo) no eixo horizontal do cosmos marubo. Seu modo de composição faz com que ele seja bastante distinto de um desenho de imaginação, numa direção similar à de outras iconografias 
pictográficas ameríndias (Severi 2007; Déléage 2011). Cherõpapa transpõe para a representação gráfica um esquema prévio referente às fórmulas verbais com as quais compõe cantos. Aqui, no entanto, "composição", tanto de desenhos quanto de cantos, não é algo exatamente derivado da imaginação ou da criação artística individual.

Este exímio cantador e xamã romey $a^{6}$ conhece um vasto repertório de fórmulas verbais transmitido entre os viventes e as entidades extra-humanas, tais como os espíritos yovevo. Seu conhecimento é atualizado a partir de uma rede virtual, na qual ficam suspensos os interlocutores potenciais do xamã e seus saberes diversos. Em sonhos e outras experiências nas quais o seu duplo (vaká) estabelece relações com tais interlocutores marcados por relações de parentesco, o conhecimento formular (mas também a farmacopeia, a onomástica, os padrões gráficos, as coreografias e as sequências rituais, entre outros saberes) pode ser parcialmente utilizado pelo cantador em uma performance específica. Tal rede virtual, portanto, nada tem de imaginária ou fictícia: sua diferença em relação ao real vivido pelos Marubo é apenas de posição e de invisibilidade, que deve ser ultrapassada pela mobilidade dos duplos dos xamãs.

Em diversos rituais, os xamãs marubo transmitem, por meio de um encadeamento sistemático, preciso e complexo, o conjunto de fórmulas que transita pelos modos de suas artes verbais (os cantos de cura shõki, as narrativas cantadas saiti e os cantos pessoais iniki, entre outros). As fórmulas se orientam, em sua maioria, através de um esquema que pretende dar conta do modo de surgimento (awẽ shovia), do trajeto ou caminho (awẽ vai) e do estabelecimento (awẽ tsaoa), em seus respectivos lugares, de agentes diversos, tais como os espíritos das sucuris, os duplos de animais, os antepassados, os espectros de guerreiros mortos e os próprios brancos ou estrangeiros. Tal estrutura triádica poderá ser deslocada para uma narrativa mítica ou para uma determinada tarefa ritual, que costuma ser realizada através dos cantos shõki. Com este esquema, torna-se possível ao xamanismo monitorar, pensar e atuar sobre espíritos potencialmente agressivos ou benfazejos, tendo em vista garantir a harmonia da vida entre parentes. O repertório aberto de fórmulas verbais se dedica a mapear o conjunto sempre inacabado de gêneses, deslocamentos e comportamentos de que se constitui o cosmos marubo.

Nesse momento, algumas breves considerações sobre a noção de pessoa se fazem necessárias. ${ }^{7}$ A pessoa é, a rigor, uma configuração de parentesco composta por duplos que se concebem como irmãos e que, para si mesmos, julgam habitar uma maloca - esta dimensão que, para nós, corresponde ao interior do corpo. O que podemos chamar de "vivente" (kayakavi, aquilo que tem o aspecto de um corpo, kaya) é, pois, uma carcaça (shaká) que abriga os duplos diversos (vakárasĩ) em seu espaço interno, uma replicação exata da 
maloca externa em que vivem os Marubo. Há uma hierarquia de nascimento entre três dos principais duplos (do coração, do lado direito e do lado esquerdo), que corresponde ao maior ou menor desempenho intelectual e xamanístico. Melhor dizendo: o duplo do coração (chinã nató), o mais velho e mais sábio da tríade, é ele também "quase como um espírito" (yovepase) e, portanto, um xamã. Por conta de suas capacidades extraordinárias - muito mais notáveis, aliás, do que as do corpo-carcaça - o duplo do coração pode sair de sua casa como quem vai passear por outras partes. Perambula pelo cosmos, visita a miríade de outros espíritos que o compõe e retorna para seu corpo-casa munido de conhecimentos. Em sua ausência, quando a casa está vazia, ele pode chamar outros espíritos ou outros duplos (de mortos, por exemplo) para cantar: esta é uma capacidade exclusiva dos xamãs romeya.

Na maloca visível ao olhar das pessoas comuns, os xamãs rezadores kẽchitxo escutam os cantos e os ensinamentos provenientes de alhures e, desta forma, põem em movimento o processo de transmissão de saberes. ${ }^{8}$ Trata-se de um sistema exocentrado, vinculado ao que certa etnologia americanista, a partir do trabalho de Viveiros de Castro (2002), tem chamado de sociocosmos - a expansão do socius para limites indefinidos, marcados por relações de parentesco. Veja o seguinte desenho elaborado por Alberto e recolhido por Montagner (1996:112), em 1983: ${ }^{9}$

\section{Figura 1 - "Xamã" (por Alberto Marubo)}

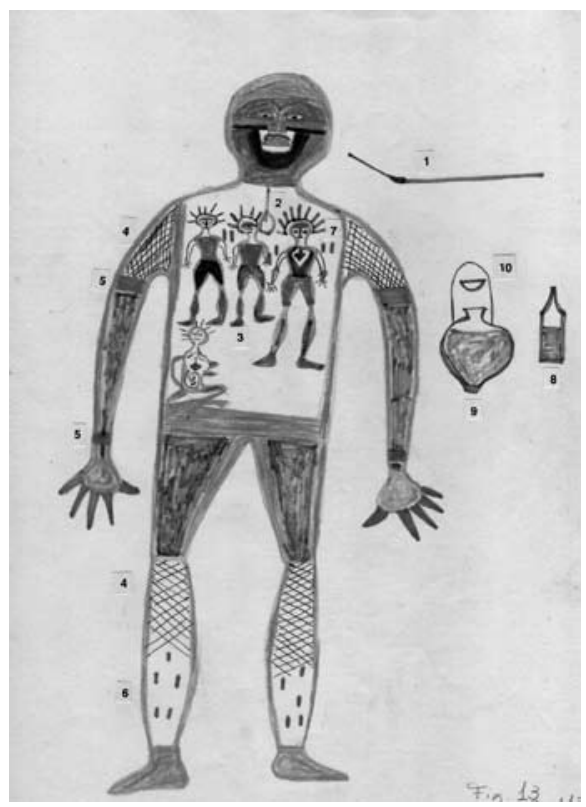


É através destes duplos humanoides internos da pessoa que o conhecimento se torna possível. "Quem não tem um auxiliar assim não sabe pensar", disse certa vez o professor Benedito Keninawa, ao se comparar com Robson Dionísio Doles Venãpa, também professor das escolas marubo, mas um destacado xamã romeya. Mas o que transmitem os duplos e os espíritos auxiliares? Eles trazem, entre outras coisas, inovações ao repertório das fórmulas poéticas ${ }^{10}$ que serão utilizadas em composições diversas (em situações de cura, em cantos pessoais, em falas cerimoniais). Tais inovações, como dizíamos, partem de um campo virtual e não constituem, portanto, um domínio de autoria ou de criação artística individual. Um outro regime de autoria decerto está aí em jogo (Cesarino 2010), já que aberto para uma configuração reticular de conhecimento e de transmissão que os próprios Marubo sintetizam bem como a seguinte expressão: "ligar pensamento" (chinã ãtinãnãi), ou seja, integrar o campo de relações com outros interlocutores viventes ou extra-humanos, todos eles conectados através da atividade dos xamãs romeya.

Para que a pessoa esteja apta a aprender e a articular fórmulas em cantos mais complexos, ela deve passar por sucessivos treinamentos xamanísticos que visam alterar as suas disposições corporais. Desta forma, torna-se mais agradável, próxima ou atrativa para os espíritos e os duplos dos quais provém grande parte do conhecimento especial. O consumo constante de substâncias como a ayahuasca (Banisteriopsis caapi) e o rapé de tabaco (Nicotiana tabacum), de dietas específicas, as aplicações de ferroadas de insetos, o uso do veneno da rã kãpô (Phyllomedusa bicolor), associados a pinturas corporais elaboradas através dos padrões kene, garantem uma alteração paulatina da pessoa que, desta forma, se torna capaz de estabelecer relações com o campo sociocósmico.

Aos poucos, o corpo se torna apto a favorecer a memória, mas é bastante singular a noção de corporalidade aqui envolvida - e também, por consequência, os sentidos possíveis do próprio processo de memorização. "Lembrar" pode ser traduzido em marubo por chinã (e "esquecer" por chinã venoa, "perder o pensamento"). Trata-se do mesmo termo utilizado para designar o mais velho daqueles irmãos ou duplos internos da pessoa: chinã nató, "núcleo do peito/pensamento". Diz-se, aliás, que os duplos estão

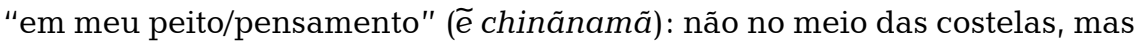
em uma espécie de dimensão ou espaço interno que eles, "para si mesmos, concebem como uma maloca" (ari ã tanáro shovorvi). ${ }^{11}$ Memória é algo relacionado ao chinã, este "espaçopensamento" que assume o aspecto de uma maloca interna, mas que integra também o nome do duplo principal que a habita (o chinã nató). 
O processo de replicação personificadora aí envolvido não se traduz bem a partir de dicotomias como corpo e mente/alma, entre outras afins. Ora, a "alma" (ou duplo, como prefiro chamar) é ela mesma (ou para si mesma) um corpo-gente (yora, noção que envolve a autorreferência sociológica e a dimensão corporal) que habita a tal maloca interna. O procedimento é reflexivo: para si mesmos, os duplos têm carne (nami), mesmo que melhor do que a desta nossa carcaça, putrescível e insensata, fadada à morte e ao esquecimento (aquela que envolve os duplos, tal como no desenho anterior). A transformação deste corpo/invólucro externo equivale ao estabelecimento do contato possível com os duplos-espíritos internos e, destes, com o sociocosmos. Aí reside o peculiar estatuto da epistemologia marubo: conhecer/ lembrar implica desdobrar-se, tornar-se outro, "ligar pensamento". ${ }^{12}$

\section{Trajetos e surgimentos}

Armando Cherõpapa diz ser uma pessoa distinta de seus parentes. Seu duplo conhece dimensões do cosmos vedadas à experiência comum e pode, assim, oferecer panoramas visuais detalhados. ${ }^{13}$ É isso que, entre outras coisas, possibilita os encadeamentos de fórmulas dos cantos: a tríade surgimento/ trajeto/ estabelecimento fornece ao sujeito a visualização, por meio de imagens mentais, dos processos de formação de agentes e aspectos diversos que compõem o cosmos. As longas sequências narrativas dos cantos saiti, por exemplo, são compostas precisamente por tais encadeamentos formulares que, em muitos casos, seguem o princípio ordenador do trajeto. Veja esta estrofe do saiti "Raptada pelo Raio" (Kaná Kawã), que visualiza o percurso pelo cosmos do Pajé Samaúma em busca de sua mulher raptada pelos raios: ${ }^{14}$

$\begin{array}{ll}\text { Yove mai tsakasho } & \text { E ali levantada } \\ \text { Wa nipa kawã } & \text { Fincada na terra melhor } \\ \text { Torá Osho yoraki } & \text { A árvore Torá Osho } \\ \text { Yora tanáini } & \text { Pela árvore sobe } \\ \text { Yove kaya apai } & \text { Pajé mais forte } \\ \text { Yove inakãi } & \text { Pajé vai subindo }[\ldots]^{15}\end{array}$

Através da história, a audiência comum tem acesso às outras paisagens, compostas, por exemplo, pela árvore Torá Osho, um enorme axis mundi que se estende entre o primeiro estrato da cosmografia marubo, a Morada da Copa das Árvores (Tama Shavá), e o segundo, a Morada do Céu-Morte (Vei Naí Shavaya). Daí em diante, sucedem-se outros tantos patamares celestes 
que são, a rigor, mundos (shavá), com seus próprios habitantes (ou o que chamamos de espíritos), malocas e costumes. Subindo pela árvore (também conhecida como Torá Tama), encontra-se um caminho íngreme pendente no céu, por onde passa a Lua e que conduz a uma morada melhor. De lá sai uma escada que chega até a Morada do Céu-Morte (Vei Naí Shavaya), ainda nesta região empírea mais baixa. Ao lado e acima da árvore Torá Tama estão também as cordas celestes naí mechpõ, que são na verdade quatro sucuris elásticas pendentes dos cantos do céu, sobre as quais o viajante pula para ser então jogado para cima, impulsionado pelos elásticos/sucuris. Vistas de longe, estão sobre as nuvens, são brancas e sucedem-se umas às outras em linhas paralelas, girando e conduzindo a pessoa de uma corda para a outra. Os duplos dos xamãs romeya e os espíritos Shoma ${ }^{16}$ sobem aos céus por estas cordas, cantando os seguintes versos:

$\begin{array}{ll}\text { Naí mechpõ ronoa } & \text { Pendentes cordas celestes } \\ \text { Atxi inivãia } & \text { Vou mesmo agarrando } \\ \text { Oĩpakevarãki } & \text { E venho aqui olhar }\end{array}$

Desta forma, a audiência comum pode formar a sua imagem das dimensões celestes tornadas visíveis pelos cantos. Mas é quando tais panoramas são completados por outras informações adicionais que se começa a adentrar nos domínios do treinamento xamanístico propriamente dito. Um homem maduro pode, se quiser, deixar de ser um auditor/espectador passivo dos panoramas transmitidos pelos xamãs. Aos poucos, ele será capaz de conhecer e de manipular os agentes e os eventos do cosmos. Uma das informações essenciais para tal etapa de conhecimento consiste, justamente, na compreensão dos processos de formação ou de surgimento, que possuem todo um repertório específico de fórmulas verbais. A sequência seguinte se refere, por exemplo, ao surgimento da árvore Torá Tama:

$\begin{array}{ll}\text { Yove tama eche } & \text { Semente da árvore-espírito } \\ \text { Tama mai rakásh } & \text { Na terra arbórea caída } \\ \text { Ari toãshki } & \text { Por si mesma brota }\end{array}$

Conhecer, aqui, significa conhecer pelo surgimento, e contam-se nos dedos os xamãs que, nos dias de hoje, dominam o assunto. O xamã (ou candidato) que souber o processo de formação deste e de outros elementos do cosmos ganha uma margem de manobra neste mundo em que, disseramme, "tudo é perigoso". Antonio Brasil Tekãpapa, o autor de tal declaração, pensava que os viventes podem a todo tempo ser atacados ou assediados 
pelos inumeráveis duplos de mortos, animais e demais espíritos que povoam o cosmos. O arsenal de fórmulas verbais dedicado a descrever os "surgimentos" ou "aparecimentos" (shovia, wenía) visa estancar esse risco. Para tanto, o cantador deve saber que encadeamentos formulares como o acima citado possuem uma estrutura ou esqueleto prévios, formados pelo cruzamento dos eixos sintagmático e paradigmático. Cada uma das posições dos versos (que, em marubo, possuem uma métrica precisa) é na realidade uma vaga aberta para ser substituída por outros elementos, que geram então distintas sequências lineares. Tome-se o exemplo da seguinte passagem, na qual Armando Cherõpapa, recitando estrofes curtas que servem como gancho para os cantos shõki, me explicava o surgimento dos duplos das bananas (isto é, os seus agentes humanoides potencialmente agressivos):

1. Vei mani rechoki

Recho avá atõsho

Yochĩ shovikãiai

Vei mani yoraki

5. Vototanáirinô

Vei mani peiki

To iki vakíchi

Ea yochĩ veõno

Iki awakãii

10. Veõnivo yochĩra

Vei mani peiki

To iki vakíchi

Kekashenãkãisho

Veõnivo yochĩra

15. Yochĩvoro eakiki
Seiva de bananeira-morte

Da seiva escorrida

Foi o espectro se formando

Para que na bananeira-morte

Ali ao lado

De sua folha-morte

Em sua sombra

Eu espectro fique

Assim vai ficando

O espectro ali sentado

Ali na folha-morte

Em sua sombra

Vai fazendo confusão

O espectro aí sentado

Espectro mesmo sou $-\operatorname{diz}^{17}[\ldots]$

O pequeno bloco (do que poderia ser um longo canto shóki dedicado a neutralizar as agressões deste espectro dirigidas aos viventes) pode ser dividido em três partes. Nos versos 1 a 3, dá-se o surgimento do espectro; nos versos 4 a 10, vemos o seu trajeto e o seu estabelecimento; por fim, nos versos 11 a 15, já "em seu lugar" (awẽ tsaoa), ele diz algo sobre os seus hábitos peculiares. Note que a sequência inicial é uma variação daquele mesmo esquema fixo que, mais acima, era utilizado para o surgimento da árvore Torá Tama: um termo saliente do primeiro verso é repetido no segundo (tama no primeiro exemplo, recho no seguinte) e a fórmula se completa no terceiro, que fecha o processo de surgimento ("por si mesmo brota", no caso 
da árvore; "foi o espectro se formando", no caso do espectro). São muitas as ocorrências de tal estrutura formular nas artes verbais. É o caso desta estrofe inicial, cujo esquema se reitera diversas vezes ao longo do "Canto de Surgimento dos Pajés" (Kẽchĩtxo Wenía):

1. Vari oni nãko

Nãko osõatõsho

Yoe shovivãi

Yove mai matoke

5. Shokoi voiya

Kevitivo vanayai

Shokoi voiya
Néctar de cipó-sol ${ }^{18}$

De dentro do néctar

Espíritos se formam

E na terra-espírito

Juntos vão viver

Sabidos e loquazes

Juntos vão viver $[\ldots]^{19}$

Mais uma vez, as três linhas iniciais indicam o modo de surgimento dos xamãs rezadores (aí referidos como "espíritos") para, em seguida, subentender um percurso que conduz ao seu lugar de estabelecimento. A fórmula inicial de surgimento possui outra informação fundamental: está marcada pelo classificador "sol", que aponta a classe particular dos pajés que aí tiveram surgimento. São diversos os pajés mencionados no cantomito, marcados cada um por seus distintos classificadores, tais como os Pajés-Azulão (Shane Kechĩ), Pajés-Jaguar (Ino Kechĩ), Pajés-Claro (Pacha Kechĩ), Pajés-Espírito (Yove Kechĩ), entre outros tantos. Tais classificadores (ou variadores cosmológicos) acabam também por diferenciar os elementos que a eles são associados: a ayahuasca da qual surgem os Pajés-Sol será ayahuasca-sol; sua terra será a Terra-Sol (Vari Mai), e assim por diante. O procedimento de variação de pessoas e entidades desencadeado por tal sistema, vale dizer, é compartilhado pela própria morfologia social marubo (Cesarino 2011a; Melatti 1977) e por todos os coletivos do cosmos. Desempenhará um papel determinante na cartografia que examinaremos a seguir. Antes, porém, veja como o próprio Cherõpapa, tendo em mente a estrutura formular do canto acima mencionado, decidiu desenhar o surgimento dos xamãs rezadores:

O desenho é uma transposição gráfica exata das fórmulas de surgimento, tal como a que está presente nos três primeiros versos do trecho acima destacado. Trata-se aí de um Xamã-Sol (Vari Kechĩ), que surge a partir do "néctar"20 de sua ayahuasca. O seu local de surgimento está representado por um signo gráfico (recorrente em outros exemplares da iconografia marubo): um pequeno círculo esboçado na parte inferior esquerda da copa da árvore. Círculos serão sempre aqui os signos aplicados para designar os processos de surgimento, mas também, em outros casos, as aldeias, as 
Figura 2 - Armando Cherõpapa, "O surgimento dos pajés", lápis de cor, grafite e caneta hidrocor sobre papel, 210 × 297 mm, 2006. Acervo Pedro Cesarino

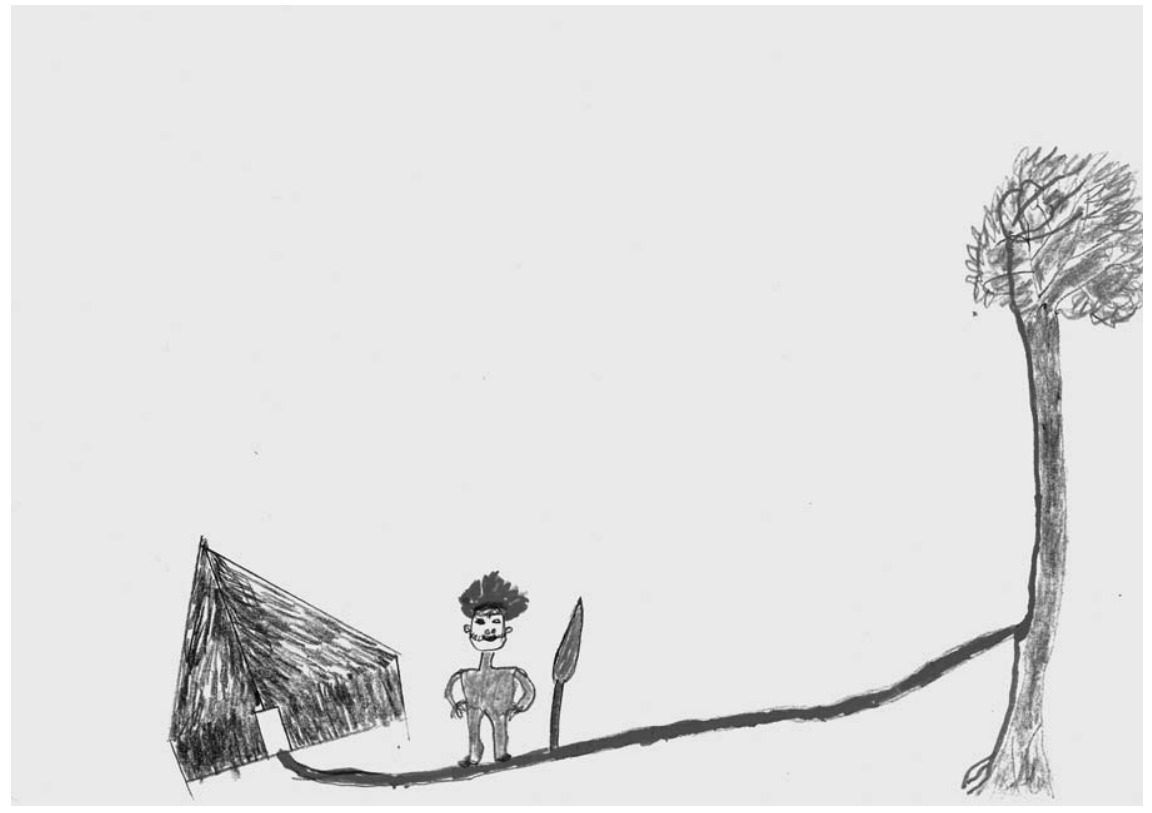

malocas e os lugares de estabelecimento. Em seguida, o xamã percorre um caminho indicado pelo traço vermelho - traço é, então, o segundo signo gráfico distintivo desta iconografia - até chegar em sua maloca. Malocas, representadas de formas diversas, junto com humanoide e árvore completam o conjunto de signos de que se valem os xamãs em seus desenhos.

Há aí um detalhe essencial: árvore é uma metáfora visual para o Povo Espírito das Árvores (Tama Yove Nawavo), que são os pais do xamã. Ao desenhá-la, Cherõpapa quis se referir a esta coletividade de espíritos. A representação de uma árvore nada tem aí de naturalista, portanto. Não apenas porque nosso conceito de natureza é incompatível com ontologias como esta, mas também porque o sentido da representação é outro - metafórico, especial. Na ausência de um conhecimento mais aprofundado sobre a metaforização essencial do discurso xamanístico, um marubo poderia muito bem tomar o presente desenho (mas também o trecho de um canto ou de uma explicação ouvida en passant) por uma mera árvore, passando ao largo de seu sentido velado. Não raro, daria sequência a um processo equivocado de transmissão do conhecimento: poderia dizer, por exemplo, que "os nossos xamãs nascem das árvores", perdendo assim o acesso à informação velada. 
A situação é hipotética, mas confirmada por outros exemplos. É o que se pode verificar no caso das fórmulas referentes ao surgimento dos antepassados, recorrentes nas narrativas cantadas Wenía. A leitura literal do canto (correspondente à tradução) diz que eles surgiram a partir de um buraco, como se vê neste trecho de abertura:

1. Vari awá chinãki

Vari mai paroke

Vari shõpa weki

We sheamashõta

5. Veõini otivo

Vari mai nãko

Nãko osõatõsho

Wení katsi inã

Pinikia avai

10. Vari shawã shakapa

Mai marak ativo

Mai raká rakai

A aki avai

Vari ima chiwãne

15. Vari mai teorai

Teorai kinisho

\author{
Vida de anta-sol \\ No canto da terra-sol \\ Ao vento de lírio-sol \\ Ao vento se junta \\ E ali assenta \\ Néctar da terra-sol \\ Dentro do néctar \\ Surgimento começa
}

Couro cansado

De arara-sol

Que a terra recobre

Na terra retorce

E logo aquelas

Pequenas formigas-sol

Sob a terra-sol

Seus túneis cavam $[\ldots]$

Composto pelas fórmulas da "fala contada" (yoã vana), essa abertura do Wenía (cuja versão completa se estende por mais de 2.000 versos) é toda formada por imagens veladas: "vida de anta-sol" (linha 1) é metáfora para o sêmen (ere) dos antepassados que, somado a um certo princípio vital feminino (poetizado pela fórmula "vento de lírio-sol", linha 3), vai se depositar nos úteros das mulheres primeiras, aí referidos como "canto da terra sol" (linha 2). Na sequência, a fórmula "néctar da terra-sol" (linha 6) se refere às mulheres antigas fecundadas (ou ao seu "óvulo", como tentava me explicar Robson Venãpa). Em seguida, "Couro cansado/ De arara-sol/ Que a terra recobre/ Na terra retorce" (linhas 9-12) é outra metáfora poética para a pele esticada dos ventres grávidos das mulheres e de seus bebês que ali dentro se revolvem.

Daí em diante, um trajeto será percorrido até o lugar definitivo dos antepassados (pertencentes ao Povo Sol, que empresta este variador "sol" aos demais elementos mencionados no canto): a imagem é de formigas abrindo caminho pelas fendas subterrâneas - metáfora, desta vez, para 
o próprio parto. Os Vari Nawavo (Povo Sol) foram os primeiros a surgir, nessa época em que ainda tinham sangue-espírito (yove imi), em que eram pessoas melhores do que os atuais viventes. Os blocos seguintes desse longo canto visualizam o surgimento dos outros povos antepassados e, em seguida, de seus feitos diversos - sempre através dos mesmos esquemas formulares, que se transformam indefinidamente. Cherõpapa, apoiado mais uma vez em tal esquema, decidiu transportar o episódio para o papel da seguinte forma:

Figura 3 - Armando Cherõpapa, "O surgimento dos antepassados" (Yora wenía) lápis de cor, grafite e caneta hidrocor sobre papel, 210 x 594 mm, 2006. Acervo de Pedro Cesarino

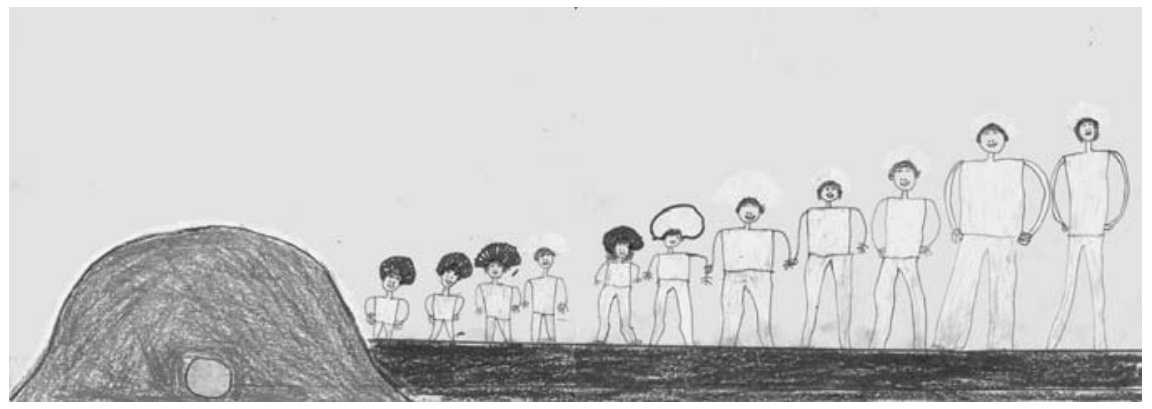

Aí está o sentido metafórico das imagens verbais transposto em imagens gráficas: no desenho, o buraco da terra (mai kini), representado à esquerda, equivale exatamente àquele trecho do canto que comentávamos acima. E não é arbitrário o uso de um círculo para designar o local de surgimento de um determinado coletivo: o signo já estava presente no desenho de surgimento dos pajés, além de aparecer em outros exemplos da iconografia. À direita do buraco na terra, os integrantes do Povo-Sol se dispõem em uma fileira que aponta para seu trajeto e para a ordem de nascimento: a figura humanoide maior, à direita, é a "mais velha" (vevoke) da série. É comum ouvir de alguns marubo menos experimentados nas artes e exegeses narrativas que seus antigos, de fato, surgiram de um buraco na terra. Ora, pessoas surgem a partir de pessoas, mesmo nos tempos primeiros. A incapacidade de acessar o sentido especial das imagens verbais acarreta, assim, distorções no processo de transmissão. ${ }^{21}$

A arte da memória veiculada pelos especialistas marubo consiste na maestria de esquemas tais como os acima expostos, referentes aos processos de formação dos antepassados, de espíritos, de árvores cósmicas. Como di- 
zíamos, há um repertório partilhado de fórmulas verbais suspenso no campo virtual de saberes. Sua consolidação parte de interações regulares entre os xamãs e seus aprendizes ao longo dos anos. Desta forma, o arcabouço aí pressuposto sugere soluções idênticas nas transposições dos esquemas narrativos (já formados por imagens mentais) para o papel, mesmo quando os dois desenhistas não partiram de decisões prévias relativas ao conjunto de signos gráficos utilizados. Note como este desenho de Paulino Memãpa se serve dos mesmos critérios que os de Armando:

Figura 4 - Paulino Memãpa, "O surgimento de Kana Voã", lápis de cor, grafite e caneta hidrocor sobre papel, 210 x 297 mm, 2005. Acervo de Pedro Cesarino

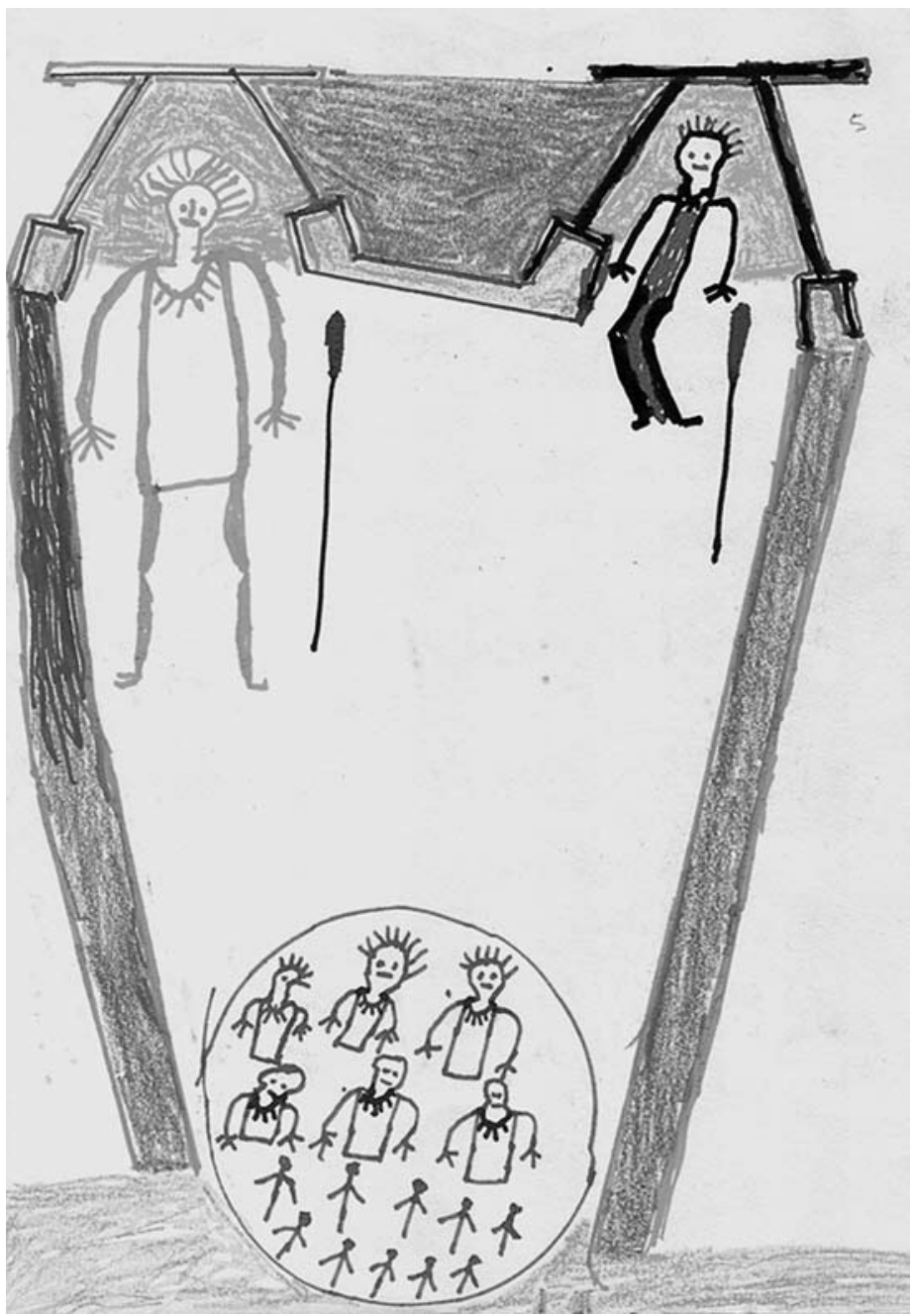


Mais uma vez, torna-se nítido o transporte entre imagens gráficas e verbais. Na parte inferior do desenho, o signo círculo indica o espaço em que surgiram os espíritos demiurgos, a partir de um vento espiralado de lírio-névoa (koi shõpa we). Daí em diante, Kana Voã, o principal espírito e fazedor de todo o cosmos, segue seu caminho (indicado através de traços) em direção ao lugar em que passará a viver (mostra aí a maloca). À direita está Roe Iso, seu sobrinho. O círculo em que surgem os espíritos transpõe para o papel uma sequência formular familiar a outras aqui examinadas. Trata-se do trecho de abertura do canto-mito "A formação da Terra-Névoa", que narra o surgimento dos espíritos demiurgos:

1. Koĩ Mai weki

We votĩnãnãki

Naí koĩ weki

Chĩkirinã atõsho

5. Ari rivi shovisho

Kana Voã akavo

Koa Voã akavo

Koĩ Voã akavo

Ave atisho
Vento da Terra-Névoa

O vento envolve

A névoa-vento do céu

E no redemoinho

Por si mesmos surgem

O chamado Kana Voã

O chamado Koa Voã

E o chamado Koĩ Voã

São mesmo eles $[\ldots]^{22}$

Os espíritos primeiros não surgem a partir de relações sexuais, mas "por si próprios" (ari shovia), de dentro de um redemoinho formado pelo encontro do vento da terra-névoa com o vento da névoa celeste. ${ }^{23}$ Veja como a fórmula em questão se baseia em um esquema similar ao presente nos versos 1 a 5 do canto Wenía: ali, os ventos estavam vinculados às metáforas para o surgimento sexuado dos antepassados; aqui, eles indicam um processo distinto de formação, exclusivo dos extraordinários espíritos primeiros.

O xamanismo marubo tem a sua ética de linguagem: a fala direta desagrada aos espíritos, bem como aos xamãs formados à maneira dos antigos. A fala metafórica, além de ser eficaz (tal como no caso da cura xamanística ${ }^{24}$ ), é também um modo de conhecimento e de respeito (ese), uma maneira de revelar relações e formas de surgimento através, diríamos nós, da elaboração poética. Atualmente, o predomínio da fala ordinária (veyô vana) tem causado efeitos sociocósmicos drásticos. As pessoas comuns, incapazes de compreender o modo elaborado a partir do qual falam os espíritos nos cantos iniki (mas também os xamãs em seus discursos), perdem a possibilidade de estender o seu campo de relações para o invisível. Interessadas apenas em suas vidas particulares e, por vezes, como no caso dos jovens, pelo universo dos brancos, param de frequentar com assiduidade as sessões xamânicas. 
Os próprios espíritos, aliás, vão aos poucos deixando de visitar as mulheres em sonho, como antes era mais comum. Por conta disso, são poucas as crianças-espírito geradas a partir de tais encontros noturnos. São elas que, tal como nossos xamãs desenhistas, poderiam um dia encadear nos cantos os longos conjuntos de imagens verbais.

Como se justifica, no entanto, minha reflexão sobre tais aspectos da língua especial marubo a partir da noção de metáfora? Cheguei a discutir a própria tradução de metáfora com professores e xamãs marubo, bastante interessados nessa noção que eu empregava com constância na tentativa de decifrar o discurso xamanístico. "Metáfora" foi por eles traduzido como "nome" (ane), um termo que se refere às fórmulas especiais diversas empregadas pelos xamãs em seus discursos (tal como "olho de onça-fogo", txi kamã vero, para "relógio", varĩ oiti na língua comum). "É nome/palavra de pajé mesmo" (kẽchĩtxo anervi), diziam-me. Seu sentido foi explicado da seguinte maneira: trata-se de algo utilizado "para compreender o surgimento [das coisas]" (anõsho awẽ shovia taná) (Cesarino 2011a). Em outros termos, os nomes ordinários das coisas (aqueles que compõem a "língua ordinária", veyô vana) não possuem qualquer potência para pensá-las ou manipulá-las através da agência ritual xamanística. Para tanto, é necessário utilizar a "fala pensada" (chinã vana) ou "soprocantada" (shõki vana), composta por tais nomes potentes.

De fato, o movimento de deslocamento de nomes ordinários para nomes especiais não deixa de recapitular a noção de metáfora em Aristóteles (Poética 21, 1457b:6-7): metaphora epiphora onoma, "transporte do nome de uma coisa para outra", mas transporte responsável por realizar um acréscimo de sentido em relação ao original (Kirby 1997:531 e segs.). Contudo, a teoria aristotélica do nome não é a mesma que a pressuposta pelo xamanismo marubo. É pouco provável, também, que tal xamanismo partilhe das dicotomias (objetivo/desviado, literal/figurado etc.) que marcam as teorias ocidentais da metáfora (Ricoeur 1975). ${ }^{25}$

Uma possível teoria da linguagem ritual marubo (e de seus transportes gráficos) deve repousar sobre outra configuração ontológica, capaz de exigir um reordenamento de cisões, tais como objetivo/subjetivo, real/fictício, literal/desviante. Não se trata aqui, portanto, de tomar as "palavras torcidas" marubo como desvios de linguagem, fictícios e arbitrários em relação a algum sentido próprio ou objetivo. Quando se diz "relógio" como "olho de onça-fogo", não se espera que esta última expressão seja menos verdadeira do que a primeira. Bem ao contrário, ela é ainda mais eficaz do que o termo disponível na fala ordinária, a ponto de ser capaz de manipular a coisa em questão: o relógio, que é propriamente "fabricado" (shovia) pelo "pensamento-palavra de pajé" (kẽchĩtxo chinã vana), assim como tantos outros fenômenos possíveis também poderiam ser. 


\section{Cartografias do cosmos}

Grande parte da iconografia marubo provém da extensa mitologia transmitida pelas narrativas cantadas saiti, muitas delas compreensíveis como panoramas sonoros e visuais. ${ }^{26}$ Além de marcar a estrutura das artes verbais, a tríade composta por surgimento, trajeto e estabelecimento se estende para outros domínios do conhecimento e da cosmologia marubo. Não por acaso, o duplo do olho (verõ yochĩ) de uma pessoa deve, depois de sua morte, fazer o caminho de volta à terra em que nasceu. A partir das experiências acumuladas em vida pela pessoa, o chinã nató, "duplo do coração/pensamento", poderá percorrer determinados trajetos que levam à morada de seus antepassados, distribuídas por locais diversos do cosmos (os estratos celestes, a morada da copa das árvores, a morada subaquática, entre outras).

Robson Venãpa, por exemplo, tornou-se xamã após realizar um longo percurso por trajetos e malocas de habitantes diversos do cosmos, até o encontro final com seus espíritos auxiliares (Cesarino 2011a, 2014). Seus relatos obedecem a um esquema cartográfico complexo, marcado pela disposição da rede hidrográfica, pelo eixo jusante/montante e, também, pelo movimento do Sol. Memória do espaço, memória dos eventos: as experiências diretas travadas alhures pelos xamãs, ou então o seu testemunho de destinos póstumos relativos aos componentes das pessoas, aprimoram e confirmam os contornos cosmográficos.

Formado por diversos estratos celestes e terrestres (aproximadamente nove, em cada uma das direções), o cosmos é entrecortado por caminhos percorridos, seja pelos próprios duplos dos xamãs, seja pelos espíritos. A Morada Arbórea (Tama Shavá) é um panorama inesgotável de malocas de espíritos, todos eles distintos entre si, falantes de línguas próprias, portadores de padrões gráficos específicos, de atributos corporais e de conhecimentos diversificados. Na Morada da Terra-Morte (Vei Mai Shavaya, este nosso mundo) ou na Morada Subaquática (Ene Mai Shavaya), onde vive, entre outras, a coletividade de espíritos das sucuris, os xamãs romeya (ou, antes, os seus duplos) estabelecem relações de parentesco, tomam esposas e têm filhos.

Vamos aqui, no entanto, nos concentrar no eixo horizontal da cartografia marubo, bastante explorado pelo pensamento xamanístico. Trata-se de uma entre outras tantas referências possíveis que compõem não exatamente um cosmos fechado ou um mundus delimitado, mas sim uma topologia marcada pela superposição indefinida de coletivos, relações e pontos de vista, ${ }_{1}^{27}$ desprovida de centro privilegiado ou de hierarquias. Acima como abaixo, proliferam pessoas em suas aldeias, com seus chefes e xamãs, seus donos ou mestres (ivo) que são, de certa forma, instanciações ou hipóstases daqueles 
coletivos por eles envolvidos (Viveiros de Castro 2002; Costa 2007; Fausto 2008; Cesarino 2010, entre outros). É esta configuração que, mais uma vez, está transposta na iconografia. Encontramos novamente uma estrutura formular no seguinte cosmograma elaborado por Cherõpapa. Observe como ele apresenta os diversos mestres dos animais que se distribuem pelo eixo horizontal, ainda aqui no patamar central do cosmos, nesta "Morada da Terra-Morte":

O desenho, que pode ser visto à direita, realizado sobre duas folhas coladas em suas margens, segue um esquema cartográfico preciso: abaixo está a região do sol nascente (naí taeri, "direção do pé do céu", ou vari oákiri, "direção de onde chega o sol"); acima, a do sol poente (naí votĩ ikitõ, "lá onde o céu encurva", ou vari katõ, "para onde vai o sol"). À esquerda, a região sul (naí parô wetsã, "canto do céu") e, à direita, a região norte (naí parôri, "outro canto do céu"). No meio da composição, Cherõpapa coloca o sol do meio-dia. Os Mĩshõ, donos dos animais (yoũni ivorasĩ), se distribuem por estas regiões, em suas respectivas moradas que, no original, estão distinguidas através de cores. As posições e as diferenças são também marcadas pelos classificadores, tal como mostra a seguinte legenda:

\section{Quadro 1}

$\mathrm{SO}$

$\mathrm{O}$

$\mathrm{NO}$

$\begin{aligned} \text { Jaguar (Ino) } & \text { Arara (Kana) } \\ \text { Mĩshõ-Jaguar (Ino Mĩshõ) } & \text { Mĩshõ-Arara (Kana Mĩshõ) }\end{aligned}$

Japó (Rovo)

Mĩshõ-Japó (Rovo Mĩshõ)

Cinza (Koro)

Mĩshõ-Cinza (Koro Mĩshõ)

$\begin{aligned} \text { Sol (Vari) } & \text { Azulão (Shane) } \\ \text { Mĩshõ-Sol (Vari Mĩshõ) } & \text { Mĩshõ-Azulão (Shane Mĩshõ) }\end{aligned}$


Figura 5 - Armando Cherõpapa, "Os mestres dos animais", lápis de cor, grafite e caneta hidrocor sobre papel, 210 x 594 mm, 2006. Acervo Pedro Cesarino

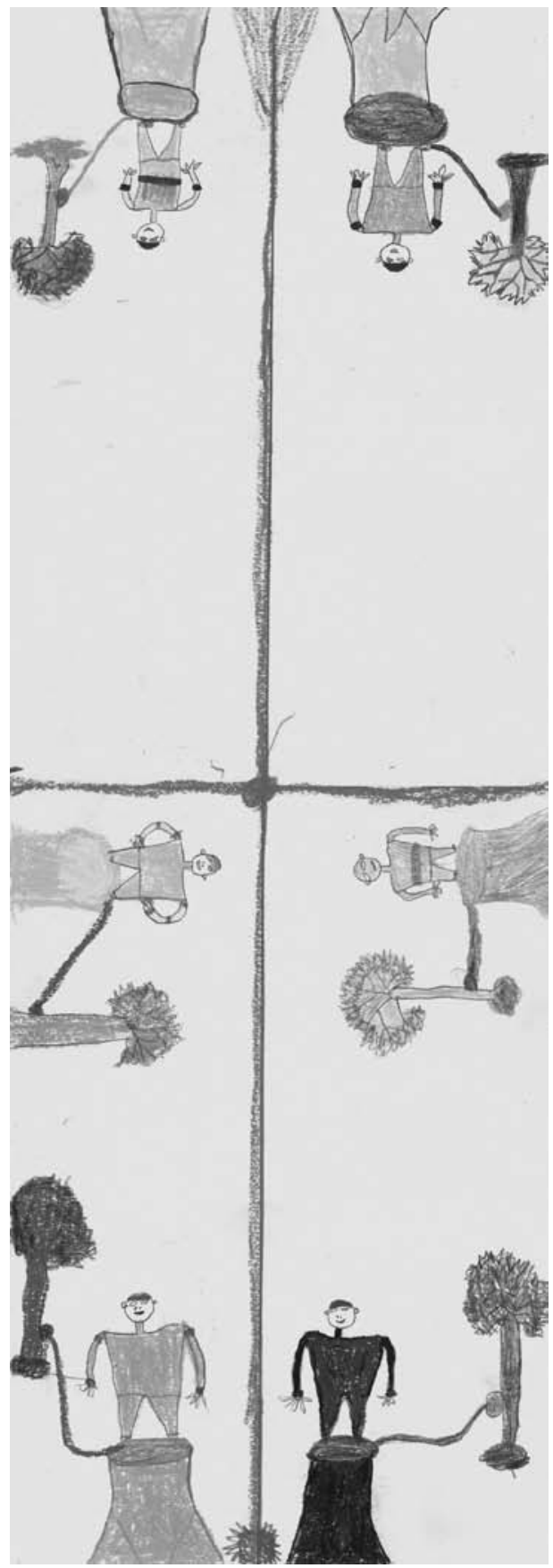


Os classificadores não podem ser confundidos com adjetivos: não se trata exatamente de atribuir qualidades a um sujeito, mas de distingui-los e de variálos em meio à rede de relações sociocósmicas. O Mĩshõ-Jaguar, por exemplo, não é um espírito felino, nem o seu parente situado a sudeste, Mĩshõ-Sol, é um espírito solar. Os classificadores indicam as seções a que pertencem os espíritos (bem como as suas distribuições no espaço), assim orientando não apenas as suas relações sociais internas, mas também aquelas estabelecidas com os Marubo. Um espírito Mĩshõ-Azulão será sempre classificado como tio materno (ou sogro em potencial) de uma pessoa que pertence ao Povo Japó (Isko Nawavo), ${ }^{28}$ pois é esta a relação que tais segmentos sociais costumam estabelecer entre os Marubo e seus outros parentes do cosmos.

Vale lembrar também que os classificadores se estendem aos outros elementos e predicados das pessoas assim diferenciadas. Os Mĩshõ-Sol, por exemplo, estão marcados com sangue de mata-pasto-sol (vari kapi imi), como indicam as pinturas dos rostos (vesekemea) e dos braços (mepokemea): os demais espíritos estão, portanto, marcados com sangue-japó, sangue-arara, sangue-cinza, sangue-jaguar e sangue-azulão. Mata-pasto (Senna alata, Cassia alata) é um arbusto florescente valorizado pelo xamanismo marubo por conta de sua grande potência agentiva (e, creio, também psicoativa): os espíritos se pintam com seu sangue (ou seiva), além de surgirem dos "néctares" (nãko) destes vegetais. O arbusto mata-pasto é utilizado para compor a fórmula (verbal e visual) referente ao lugar em que vivem os mestres dos animais: seus troncos (kapi voro) transformam-se em nomes ou metáforas para as aldeias construídas em suas colinas (matô anervi, awẽ shavárvi, "é nome de colina, da morada deles", diziam).

Os seis esquemas pictográficos acima representados podem ser considerados como uma configuração composta: trata-se de transposições gráficas de fórmulas verbais antroponímicas e toponímicas. Elas indicam, em outros termos, o nome do espírito em questão e o lugar em que ele vive. Transpõem novamente, e de uma forma bastante condensada, o surgimento, o trajeto e o estabelecimento das entidades em questão. As árvores são aquelas que dão surgimento aos espíritos (tal como na figura 2), como indica o círculo traçado em seus troncos. A partir daí, o espírito percorre um caminho que leva à sua morada (maloca ou aldeia), metaforizada como um tronco de árvore. É aí, precisamente, que está a conjunção entre o antropônimo (o espírito em pé) e o topônimo (o tronco de árvore). No desenho original, os troncos sempre acompanham as cores de seus donos: estas, somadas à posição em que ocupam na página (obedecendo à sua localização exata na cartografia mítica), indicam o segmento do sociocosmos a que pertencem (marcado pelos distintos classificadores, azulão, sol, cinza, jaguar, arara e japó). Não é demais lembrar que cada um dos signos que compõem esses pictogramas corresponde a uma fórmula verbal precisa, seguindo 
a orientação geral da iconografia marubo. O conjunto dos seis pictogramas que forma a composição geral do desenho se refere, por sua vez, à exata distribuição no espaço dos mestres dos animais. Veja o quadro:

\section{Quadro 2}

\section{Ino Mĩshõ Kana Mĩshõ}

"surgido do néctar de mata-pasto-jaguar" "surgido do néctar de mata-pasto-arara" (ino kapi nãkõsh wenía) (kana kapi nãkõsh wenía)

"no tronco de mata-pasto-jaguar/ lá foi viver" (ino kapi voro masotanáiri/ nioi kaoi)

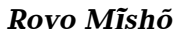

"surgido do néctar de mata-pasto-japó" (rovo kapi nãkõsh wenía)

"no tronco de mata-pasto-japó/

lá foi viver"

(rovo kapi voro masotanáiri/

nioi kaoi)

"surgido do néctar de mata-pasto-sol" (vari kapi nãkõsh wenía)

"no tronco de mata-pasto-sol/ lá foi viver" (vari kapi voro masotanáiri/ nioi kaoi)

Vari Mĩshõ "no tronco de mata-pasto-arara/ lá foi viver" (kana kapi voro masotanáiri/ nioi kaoi)

\section{Koro Mĩshõ}

"surgido do néctar de mata-pasto-cinza" (koro kapi nãkõsh wenía)

"no tronco de mata-pasto-cinza/ lá foi viver" (koro kapi voro masotanáiri/ nioi kaoi)

"surgido do néctar de mata-pasto-azulão" (shane kapi nãkõsh wenía)

"no tronco de mata-pasto-azulão/ lá foi viver" (shane kapi voro masotanáiri/ nioi kaoi)

\section{Shane Mĩshõ}


Aí estão as fórmulas de surgimento e de estabelecimento utilizadas para a transposição gráfica dos esquemas desses seis mestres de animais, todas elas distribuídas pelas regiões. Os mestres dos animais não surgem apenas do "néctar" dos arbustos de mata-pasto, mas também através de outros processos pensados a partir das seguintes fórmulas, que apontam para suas formações contínuas: "surgidos do fluxo da seiva" (recho avá atõsh wení), "surgidos a partir das flores caídas" (owa menokotõsh wení), "surgidos a partir das folhas caídas" (pei menokotôsh wení). ${ }^{29}$ Vemos assim como a presente cartografia se distingue dos desenhos até então apresentados (ainda que se baseiem nos mesmos esquemas formulares): não transportam apenas um episódio específico da mitologia, mas exibem também um plano sincrônico, uma distribuição espacial dos mestres dos animais. A diacronia não deixa de se fazer presente no interior dos seis pictogramas compostos, que tornam visíveis as trajetórias biográficas (os surgimentos) de cada um dos espíritos.

A configuração espacial pode ser empregada para outros elementos desta paisagem do eixo horizontal do cosmos: tal como na estrutura geral das fórmulas verbais, aqui também a memória mantém as posições e as ordens fixas, indicadas pela distribuição dos classificadores, e troca os nomes referentes a entidades e outros elementos da cartografia. Veja-se, na página seguinte, como Cherõpapa se utiliza da mesma distribuição espacial, desta vez para as árvores.

As árvores aí representadas não se referem a fórmulas verbais específicas, mas sim a exemplares de suas multidões espalhadas pela floresta. A armadura espacial, no entanto, é idêntica à do desenho anterior, e nos interessa precisamente por isso. Vale aí a mesma distribuição dos classificadores: à esquerda, no leste, vemos abaixo as samaúmas-azulão (shane shono) e as envireirasazulão (shane shai); acima, por sua vez, estão as samaúmas-sol (vari shono) e as envireiras-sol (vari shai). À direita, no oeste ou nas cabeceiras, estão as samaúmas-arara (kana shono), as envireiras-arara (kana shai) e as árvores-desenho (kene tama). ${ }^{30}$ Acima (sudoeste) estão as samaúmas-jaguar (ino shono), as envireiras-jaguar (ino shai) e as árvores-macaco-barrigudo (txona tama). ${ }^{31}$ (Note que a discrepância entre o número de árvores desenhadas e a quantidade identificada pelo desenhista em sua explicação não é arbitrária, já que as árvores têm aí um valor metonímico). Ao norte estão as samaúmas-cinza (koro shono) e as envireiras-cinza (koro shai), coloridas em salmão. ${ }^{32}$ Ao sul, por fim, estão as samaúmas-japó (rovo shono) e as envireiras-japó (rovo shai).

São diversas as árvores que podem ser assim identificadas, no mesmo esquema capaz de mapear os mestres dos animais e também os próprios animais e certos fogos subterrâneos (associados ao que chamamos de "vulcão"), ou então as ventanias pertencentes, muitas delas, às próprias árvores apresentadas no 
Figura 6 - Armando Cherõpapa, "Árvores", lápis de cor, grafite e caneta hidrocor sobre papel, 297 x 420 mm, 2006. Acervo de Pedro Cesarino

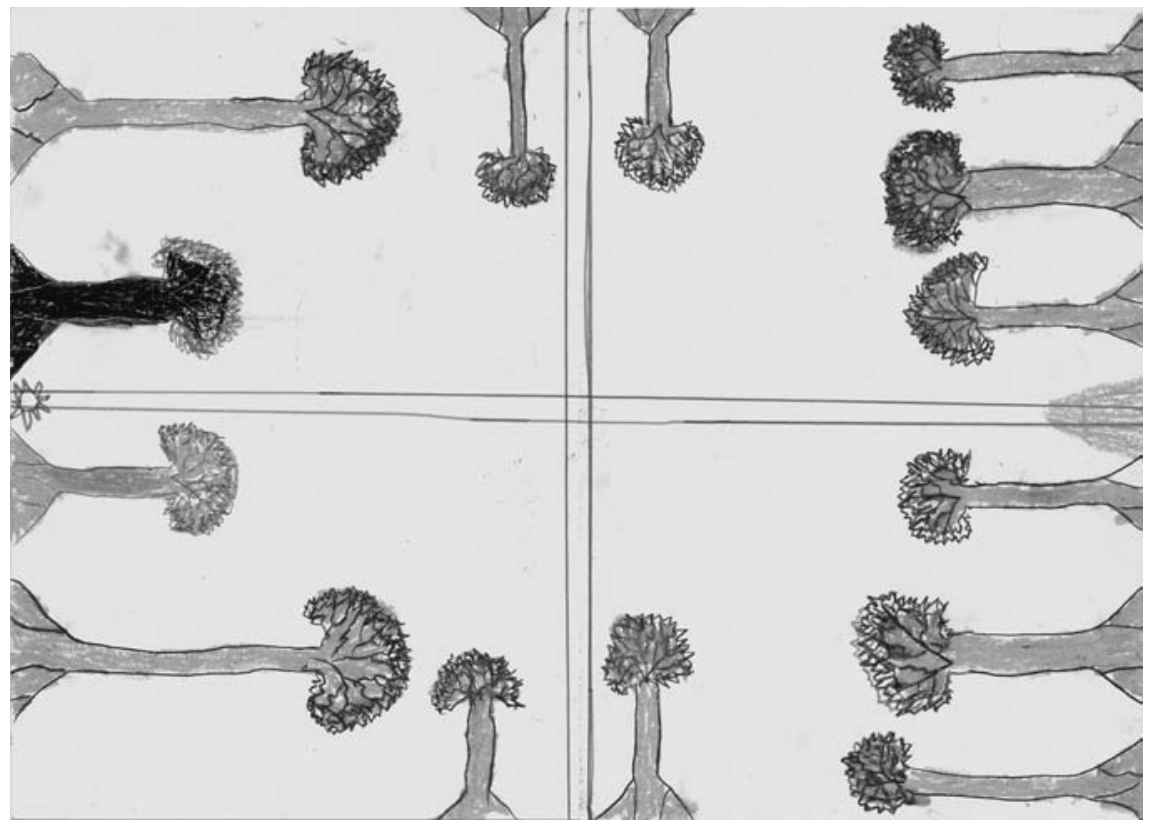

desenho. Os xamãs costumam chamar tais ventos de árvores em determinadas festas, a fim de amenizar os males e as doenças desta terra. Quando executados, os distintos blocos do longo Canto de Chamado do Vento (We Kená) seguirão rigorosamente a distribuição espacial marcada pelos classificadores.

É importante dizer que a divisão por pontos cardeais não traduz exatamente a configuração da cartografia, orientada, mais exatamente, pelo caminho do sol e pelo eixo jusante/montante. Este último eixo é aquele que confere à espacialidade marubo uma carga temporal. Os eventos que ocorreram a jusante, na região do grande rio (noa) identificado ao Solimões, são mais antigos, pois esta é a região em que sucederam os episódios dos "tempos do surgimento" (weníatiã), como o surgimento dos antepassados narrado no canto Wenía. Daí em diante, os antigos passaram a viajar em direção às cabeceiras (no sentido do poente). Através de sucessivas guerras, alianças e reconfigurações sociopolíticas, os antepassados deram origem à atual distribuição dos Marubo (e de suas respectivas seções) pelo eixo horizontal. Além de os classificadores indicarem as direções em que vivem os mestres dos animais, eles se estendem também à própria distribuição dos antigos segmentos (ou nawavo) que vieram se estabelecer na região entre as cabeceiras dos rios Ituí e Curuçá. 


\section{Considerações finais}

Na transposição gráfica de esquemas narrativos ou espaciais, vimos como o pensamento marubo lança mão de um mesmo procedimento de substituições e variações formulares. A aquisição de tal saber se encontra atrelada à transformação da pessoa e à sua articulação com o campo sociocósmico. Entre os Marubo, mas também em diversos outros xamanismos ameríndios, o campo transformacional e extra-humano veiculado pelas narrativas míticas permanece suspenso no virtual. Muitas regiões e vários personagens encontrados nas narrativas podem assim ser acessados pelos duplos dos xamãs romeya, que então transportam sua experiência imediata aos viventes. Aí reside uma diferença do registro de memória dos xamãs rezadores em relação aos romeya: para estes últimos, a experiência imediata torna-se uma vantagem adicional, que vem se somar ao arcabouço formular passível de ser adquirido através dos processos de iniciação e/ou alteração da pessoa.

Os dois tipos de xamanismo visam, porém, atingir um resultado similar: o desdobramento ou a multiplicação da pessoa em seus duplos-irmãos e demais espíritos auxiliares. Mas o caso dos romeya é realmente único no que se refere às suas capacidades de externar voluntariamente seus duplos em direção às regiões outras, bem como de integrar efetivamente outros campos de parentesco. É esse trânsito constante entre os dois níveis epistêmicos (referentes à informação mediada e imediata, transportadas ao longo da cadeia narrativa ou vivenciada alhures pelos duplos dos xamãs) que possibilita a manutenção de um vasto repertório de cantos e narrativas, cuja sobrevivência não depende de alguma convivência (passada ou presente) com a escrita. ${ }^{33}$ É dessa forma também que vem à tona o repertório iconográfico aqui examinado através das estruturas formulares mobilizadas para a composição de cantos.

Os saiti, por exemplo, constituem um conjunto de mais de duzentos episódios integrados em ciclos narrativos, todos eles metrificados e versificados, capazes de se estenderem por dezenas de milhares de versos ao serem transcritos e traduzidos. Algo bastante distinto daquele pressuposto, hoje em dia obsoleto, partilhado por autores como Goody (1994 [1993]:183 e segs.), que identificava uma defasagem da memória na dita "oralidade pura" por contraposição à sua ampliação viabilizada pelas interfaces com a escrita. ${ }^{34}$ As artes verbais marubo não revelam facilmente suas particularidades a partir de um contraste assimétrico com a escrita e suas aquisições: elas exigem um outro conjunto de pressupostos para o seu estudo, do qual oferecemos aqui apenas alguns aspectos. ${ }^{35}$ Trata-se, assim, de apontar para um outro regime qualitativo de disposição da memória através de palavras e de imagens, incompreensível 
pela ideologia evolucionista que se fazia presente também nos estudos que consideravam as pictografias ameríndias como passos abortados no caminho para a escrita (Severi 2007:91 e segs.; Déléage 2009, 2011) ${ }^{36}$

O savoir par coeur encontra aqui uma formulação original: os duplosespíritos internos não são como os imagines agentes de que lançavam mão os primeiros textos sobre as artes da memória estudadas por Frances Yates (2000 [1966]:26 e segs.). Não se trata de artifícios de imaginação, mas de desdobramentos da pessoa. A sede do pensamento e da memória é o peito, habitado por duplos chamados de chinã, todos eles cobertos por padrões com os quais se torna possível apreender as línguas dos coletivos distintos do cosmos, as direções precisas de suas moradas, os seus costumes, os seus cantos. Estaríamos aí diante de memórias que se aperfeiçoam pelo emprego de técnicas consolidadas (Yates 2000 [1966]:34 e segs.)? Ainda que ela seja fundamental, não cabe aqui reificar a técnica, sob o risco de inviabilizar a compreensão da pessoa múltipla, essencial para o entendimento da epistemologia marubo e seus processos de aquisição de conhecimento.

$\mathrm{Na}$ tentativa de investigar os pressupostos do regime xamanístico de conhecimento, evitei aqui recorrer a alguma teoria geral externa. ${ }^{37}$ Ao invés de tomar teorias (da psicologia, por exemplo) e aplicá-las aos dados, busquei antes mostrar como a etnografia projeta um contorno teórico próprio. O aporte teórico em questão se baseia na articulação da tríade surgimento/trajeto/estabelecimento com a relação entre experiência mediada e imediata (deferência e ostensão).$^{38} \mathrm{~A}$ tríade é, de fato, uma abstração dos critérios mobilizados pelos pajés marubo em suas reflexões sobre as trajetórias biográficas, escatológicas e iniciáticas, bem como sobre processos de formação de espíritos e demais elementos do cosmos. Tal abstração - assim caracterizada por mim a partir de formulações sistemáticas realizadas pelos próprios xamã ${ }^{39}$ - ganha corpo através de processos de transmissão e aprendizagem marcados pela relação entre os dois níveis epistêmicos, o ostensivo e o deferencial.

Essa passagem do imediato ao mediado garante a continuidade, a eficácia e a validade da tríade formular. Diversos são os momentos em que se torna notável tal passagem. Ao longo de processos de ensino e transmissão dos cantos shõki e de sua aplicação ritual, por exemplo, os aprendizes escutam dos mais velhos explicações sobre determinados agentes agressores feitas através dos três momentos em questão que compõem a estrutura dos cantos. A veracidade e a acuidade de tais explicações são validadas tanto pela recorrência dos ensinadores a alguma fonte de autoridade superior (um pajé vivo ou morto, visível ou invisível, por vezes ali presente em pessoa através do corpo/maloca de um romeya), quanto pela experiência de contato direto com o modo de surgimento de uma determinada entidade ou fenôneno 
(em experiências diversas, visionárias ou não, que passarão em seguida a alimentar a cadeia deferencial). ${ }^{40}$

Torna-se claro, desta forma, que o ponto de articulação entre os dois registros de experiência responsáveis pela produção dos critérios de conhecimento em questão, bem como de seus modos de expressão, é a própria pessoa múltipla. ${ }^{41}$ Sem ela não seria possível fazer com que os interlocutores outros intercedessem junto aos viventes e se presentificassem nas sessões xamânicas, a fim de validar e transmitir os conhecimentos rituais; tampouco seria possível, para os próprios aprendizes e pajés rezadores, manter e aprofundar a formação de seus duplos internos, sem os quais a pessoa não seria capaz de pensar.

É por isso que a ontologia marubo se mostra mais próxima de determinadas teorias do virtual do que dos dilemas psicológicos derivados da cisão moderna entre interior e exterior. ${ }^{42}$ Semelhante aproximação não é novidade para a etnologia americanista, mesmo que ainda mereça ser explorada com mais profundidade. Lévi-Strauss já havia mostrado na famosa abertura de O cru e o cozido como o pensamento narrativo ameríndio não poderia se acomodar senão em um ambiente virtual (1964:13). O caso marubo, por sua vez, evidencia as condições de produção, de circulação e transformação de tal conhecimento (particularmente em sua expressão formular e visual) a partir de um ambiente similar. Digamos assim que a virtualidade cosmológica é responsável pela atualidade epistemológica, de maneira análoga àquela pela qual Viveiros de Castro entendeu a afinidade potencial como "a virtualidade de que o parentesco é o processo de atualização" (2002:412).

Aliás, é exatamente através de relações de afinidade que, entre os Marubo, pessoas viventes (ou, a rigor, seus duplos ou aspectos) se relacionam com as redes virtuais do parentesco sociocósmico, assim impulsionando os processos de transmissão de saberes. Não por acaso, a atualização, ou a diferenciação, como dizia Deleuze (1988:340), é uma forma de criação — fenômeno notável nas variações de composição efetuadas através do repertório de fórmulas verbivisuais. Essa tecnologia de transporte entre o virtual e o atual de que se valem os xamãs possibilita a transmissão das fórmulas verbais e a consolidação de uma memória visual topográfica, marcada por indefinidas possibilidades de variação, substituição, concatenação e justaposição, notável na complexa relação entre os cantos e a iconografia pictográfica que aqui tratamos de estudar. 
Pedro Cesarino é professor do Departamento de Antropologia, USP. E-mail: <pedroncesarino@uol.com.br>

\section{Notas}

* As distintas etapas de pesquisa que deram origem a este artigo foram realizadas com o apoio do CNPq, da Faperj (Projeto Pronex NuTI), do Centre National de la Recherche Scientifique (C.N.R.S.), da Wenner-Gren Foundation, da Fapesp e da Fundação Ford. Agradeço a Carlo Severi, Carlos Fausto, Pierre Déléage, Anne-Christine Taylor e Sophie Moiroux pelos comentários a versões anteriores deste trabalho.

${ }^{1}$ Ver Cesarino (2012) para um estudo sobre os padrões kene.

${ }^{2}$ Para outros estudos sobre a interface entre desenhos e artes verbais entre os Marubo, consulte Cesarino (2011a, 2011b).

${ }^{3}$ O sentido complexo da noção de yochĩ não será discutido aqui. Veja Cesarino (2011a:183-205, 2011c) para mais detalhes.

${ }^{4}$ A interface entre linguagem e grafismo é aqui determinante: os desenhos em questão existem apenas como transposições de fórmulas verbais que, por sua vez, possuem uma carga visual toda própria e irredutível às querelas ocidentais em torno da divisão de gêneros e fusões de categorias (Mitchell 1986). Por conta de seu estatuto intersemiótico, os problemas aqui analisados se afastam também, e por outro viés, das críticas de Gell em Art and agency à excessiva impregnação de paradigmas linguísticos e semióticos nas artes visuais e nos estudos etnológicos que marcaram as décadas de 1970 e 80 . Gell tem razão em sua crítica (aliás, partilhada por teóricos diversos da imagem e da arte, tais como Mitchell, Belting, Didi-Huberman, Debray, Cauquelin e outros), mas ela não se aplica completamente aos presentes materiais (tal como, noutra direção, aos dados analisados por Nancy Munn [1973] em seu livro sobre os Walbiri da Austrália).

${ }^{5}$ No horizonte pano, há afinidades entre o acervo recolhido por mim e um conjunto de desenhos dos Shipibo-Conibo apresentados por Bertrand-Ricoveri (1994): também ali estão moradas e humanoides ligados por trajetos, referentes à cosmologia de tal povo. Vale também se referir a um repertório de desenhos dos Matsiguenga coletados por Baer (1994). A conexão entre esquemas verbais e visuais não é uma particularidade do caso marubo e possui semelhanças com outros repertórios ameríndios, que ainda precisam ser explorados com mais profundidade. No que se refere 
especificamente à interface entre cantos e produções visuais através de metáforas, vale se reportar aos exemplos compilados por Severi (2007) e também, noutra direção, ao estudo de Sekaquaptewa e Washburn (2004) sobre a relação entre cultura material e artes verbais entre os Hopi.

${ }^{6}$ Veja nota 8 abaixo para uma definição de romeya.

${ }^{7}$ Desenvolvo em outro lugar (Cesarino 2011a) um estudo mais detalhado a respeito da pessoa marubo.

${ }^{8} \mathrm{Tal}$ é, pois, a diferença essencial entre os dois tipos de xamanismo existentes entre os Marubo: a capacidade de externar os duplos e a de receber outros dentro de si (característica dos romeya) versus a atuação através de cantos e de espíritos auxiliares (uma prerrogativa dos kẽchĩtxo). Os dois tipos remetem à divisão de Hugh-Jones (1994) entre xamanismo vertical e horizontal na Amazônia, recentemente reavaliada por Viveiros de Castro (2007) e sua noção de "xamanismo transversal".

${ }^{9}$ Alberto representou aí quatro espíritos auxiliares do xamã, dentro de seu tórax. Na margem direita, diz Montagner em seu livro (1996:112), estão as parafernálias xamânicas: o inalador de rapé rewe (acima), a garrafa de ayahuasca (à esquerda) e uma garrafa com rapé de tabaco (à direita). Os traços das panturrilhas do xamã são os rome, dardos ou projéteis mágicos que o fazem dançar. A figura está ainda com braçadeiras e pulseiras de aruá (novo), mais as suas pinturas corporais.

${ }^{10}$ Entendo "fórmula" no sentido dado por Lord (1965) em seus estudos sobre a composição oral. Nagler (1967; rediscutido por Goody 1994:101 e segs.) ofereceu uma definição alternativa interessante a partir do paradigma gerativista.

${ }^{11}$ a-ri ã taná-ro shovo-rvi [3pess.demonstrativo-reflexivo 3pess.dem.genitivo entender-tópico maloca-enfático].

${ }^{12}$ Maiores considerações sobre chinã estão em Cesarino (2011a:38 e segs.). Veja também Déléage (2006) para os Sharanawa, Kensinger (1995) para os Kaxinawá, Naveira (2007) para os Yaminawa, entre outros.

${ }^{13}$ Noutro trabalho (Cesarino 2011a), apresento uma análise de um desses panoramas referentes ao Caminho dos Mortos (Vei Vai).

${ }^{14}$ Neste artigo os termos "pajé" e "xamã" designam os mesmos especialistas rituais e são, portanto, sinônimos. Emprego apenas o primeiro quando se trata de traduzir nomes ou cantos, por ser o mais próximo do português utilizado pelos Marubo.

${ }^{15}$ Versão integral publicada em Cesarino (2011a:355 e segs.; 2013:85 e segs.).

${ }^{16}$ Trata-se de uma multiplicidade de espíritos femininos espalhada por toda parte do cosmos, que os xamãs rezadores (kẽchĩtxo) costumam evocar em seus cantos shõki a fim de cumprir tarefas diversas. Veja Cesarino (2011a:229 e segs.) para mais dados a respeito. 
${ }^{17}$ Versão integral publicada em Cesarino (2011a:206 e segs.). Neste trecho, Cherõpapa imita ou reproduz o que diz o espírito sobre si mesmo, isto é, sobre o seu processo de formação (o uso do reportativo - $k i$ atesta isto). O espírito, porém, não está aí presente falando através do xamã, tal como ocorre na estrutura enunciativa dos cantos iniki (Cesarino 2011a, 2011b).

18 "Cipó" é o termo que utilizo para ayahuasca (oni) ao traduzir os cantos.

${ }^{19}$ Versão integral publicada em Cesarino (2011 a:112 e segs.).

${ }^{20} \mathrm{O}$ termo nãko tem sentidos diversos: designa uma espécie de fruto do tamanho de uma maçã utilizada como alimento pelos espíritos (hiperalimento que os sacia completamente quando ingerido), as seivas adocicadas extraídas de determinadas árvores (não identificadas) que são consumidas pelos humanos em rituais diversos e, também, um princípio de transformação através do qual surgem espíritos e demais agentes. Este último sentido, que não tem uma tradução determinada, pode por vezes designar metaforicamente o sêmen, por exemplo, dos antepassados (neste caso, nunca ao longo de um canto se dirá ere, sêmen, mas sempre nãko). Na falta de uma tradução única e objetiva para o termo, adoto uma solução que condensa algumas das características espalhadas pelos sentidos acima descritos: néctar (substância adocicada, hiperalimento e, aqui, também princípio transformacional).

${ }^{21}$ A despeito de seu sentido velado entre os Marubo, o surgimento a partir de um buraco na terra (da fenda aberta em uma rocha ou de outras configurações análogas) é recorrente em mitologias e iconografias ameríndias. No caso pano, uma versão similar do Wenía é contada pelos Katukina (Acre) da seguinte forma: "Os Katukina vieram debaixo da terra. Logo que surgiram não havia mulheres, somente homens (Mai rokẽ nenoash shovii nivoani aĩ vovonõq honivovonõã weste shovi teashẽ)". A história, compilada em um livro de educação escolar indígena, é acompanhada por um desenho de estrutura bastante similar ao de Cherõpapa: a partir de um buraco, os antigos surgem e seguem um caminho traçado à direita da página (Katukina \& Sena s/d:4 e segs.). Vale também se reportar ao exemplo dos mitos enawenê-nawê (Silva 1998), da iconografia tukano comentada por Ribeiro (1992:41, fig. 7) e, também dos relatos inca compilados por Garcilaso de la Vega (ed. 2005, cap. XVI:42; cap. XVIII:47.), entre outros possíveis. Na América Central, é notável a representação da gruta-útero de Chicomoztoc na Historia Tolteca-Chichmeca (http://gallica.bnf.fr/ ark:/12148/ btv1b84559448/f13.image.r=.langPT). Ela explicita de maneira eloquente essa relação entre terra e ventre materno.

${ }^{22}$ Veja Cesarino (2013:69 e segs.) para a versão integral da tradução.

${ }^{23} \mathrm{Na}$ explicação do desenho, Memãpa disse que se tratava de um "vento de lírionévoa", que não consta nesta versão do canto fornecida por ele mesmo. Trata-se, de toda forma, de variações em torno destes ventos primeiros e seus poderes transformativos.

${ }^{24}$ Veja, por exemplo, Cesarino (2011a), Townsley (1993), Déléage (2006) e Buchillet (1997) para maiores considerações sobre metáforas xamanísticas e eficácia. 
${ }^{25}$ Veja Cesarino (2003) para um estudo bibliográfico específico sobre o assunto.

${ }^{26}$ Veja Cesarino (2011a, 2011b) para uma exposição mais detalhada de tais transposições. Werlang (2001) desenvolve considerações similares sobre os cantos saiti.

${ }^{27}$ No sentido de Lima (1996) e Viveiros de Castro (2002).

${ }^{28}$ Isko Nawavo e Rovo Nawavo são, ambos, traduzidos por Povo Japó, mas representam segmentos distintos da morfologia social, que se organizam entre si através de relações de afinidade (veja Melatti [1977] para mais informações sobre o parentesco e a morfologia social marubo).

${ }^{29}$ Em certas narrativas, os Mĩshõ aparecem como tricksters. Os que estão mencionados no desenho e distribuídos pela cartografia cósmica são, porém, espíritos auxiliares (mas agressivos se maltratados) que devem ser tratados com respeito.

${ }^{30}$ Kene é outro classificador associado a tal região (referente, talvez, a um extinto subgrupo Kene Nawavo, Povo Desenho).

${ }^{31}$ Txona é outro classificador associado a tal região, na qual viviam os antigos Txonavo, o Povo Macaco-Barrigudo.

${ }^{32}$ Koroka é um termo que traduz uma gradação cromática: shane koroka, por exemplo, é o que chamamos de azul celeste (e shane, aliás, é um matiz que engloba tonalidades entre o verde e o azul); koroka, por si só, seria algo próximo do acinzentado. Note que Cherõpapa não parece atrelar de modo rigoroso as cores às posições espaciais.

${ }^{33}$ Os Marubo devem ter travado contato com a escrita alfabética no início do século XX. Sua relação mais sistemática vai se desenvolver a partir dos anos 1950, quando uma sede da Missão Novas Tribos do Brasil se estabelece no alto Ituí. Notese, aliás, a inexistência de qualquer espécie de artefato ou instrumento mnemônico, tal como os quipus andinos e os wampuns iroqueses. Ainda assim, os encadeamentos formulares (em cantos e em desenhos) se valem de ordens e sequências definidas: os mesmos princípios constitutivos de tais artefatos empregados, diga-se de passagem, não apenas para realizar cômputos, mas também para decodificar longas sequências narrativas (Déléage 2009; Urton 1998).

${ }^{34}$ Veja Carruthers (1990:31 e segs.) para uma revisão desses pressupostos.

${ }^{35}$ Esta arte da memória se forma, portanto, em um contexto distinto daquelas técnicas sistematizadas por Simônides de Ceos, já em um ambiente de interface com a escrita (Yates 1966:43).

${ }^{36}$ Veja Cesarino (2012) para um estudo específico sobre a relação entre escrita, oralidade e grafismos entre os Marubo e outros povos ameríndios. 
${ }^{37}$ Ver, por exemplo, Nagler (1967) e seu artigo sobre as fórmulas homéricas à luz do gerativismo; Bakker (1990) para um estudo mais recente sobre a formação de imagens mentais em Homero; Noll (1985) para um estudo das imagens mentais xamanísticas por meio da interface com teorias psicológicas; e Boyer (1990) para generalizações sobre o conhecimento tradicional. O presente estudo se desenvolveu por uma concepção antropológica distinta, para a qual interessa mais a reflexão mediadora (tal como a proposta por Wagner [1975] ou Strathern [1988]) do que a explicação generalizadora.

${ }^{38}$ Franchetto (2007) oferece um bom estudo sobre o assunto, discutido também por Déléage (2006) e Carneiro da Cunha (2009:365 e segs.), entre outros.

${ }^{39} \mathrm{O}$ ponto pode ser encontrado em um depoimento do xamã Armando Cherõpapa sobre o processo de formação dos espíritos, traduzido em Cesarino (2011:205 e segs.).

${ }^{40}$ Veja Cesarino (2014, no prelo) para um estudo sobre as viagens, a produção de conhecimento pela experiência imediata e os relatos biográficos do xamã Robson Marubo.

${ }^{41}$ A multiplicidade constitutiva da pessoa marubo não é algo isolado no panorama ameríndio. Lima (2005:121-122) notou algo semelhante entre os Juruna, assim como Pitarch (2000:131) entre os Tzeltal e Costa (2007) entre os Kanamari. Luciani (2001) realizou também um exercício de reflexão sobre o assunto.

${ }^{42}$ Lévi (1996) oferece uma apresentação geral da questão do virtual, desenvolvida em obras de Deleuze, tais como Différence et répétition (1968) e "Michel Tournier et le monde sans Autrui" (1969), e de Deleuze e Guattari, tais como Mille plateaux (1980) e Qu'est-ce que la philosophie? (1991), que serviram de referência para a formulação da noção de perspectivismo e de afinidade potencial por Viveiros de Castro (2002:412). 


\section{Referências bibliográficas}

BAER, Gerhard. 1994. Cosmología y shamanismo de los Matsiguenga. Quito: Ediciones Abya-Yala.

BAKKER, Egbert. 1990. "Homeric discourse and enjambement: a cognitive approach". Transactions of the American Philological Association, 120:1-21.

BERTRAND-RICOVERI, Pierrette. 1994. Vision blanche/vision indienne. Traversée anthropologique d'une culture amazonienne: les Shipibo de l'Ucayali. Thèse de Doctorat, Paris V - Sorbonne.

BOYER, Pascal. 1990. Tradition as truth and communication: a cognitive description of traditional discourse. Cambridge: Cambridge University Press.

BUCHILLET, Dominique. 1997. "Nobody is there to hear". In: J. Langdon \& G. Baer (orgs.), Portals of power. Albuquerque: University of New Mexico Press. pp. 211-231.

CARNEIRO DA CUNHA, Manuela. 2009. Cultura com aspas. São Paulo: Cosac Naify.

CARRUTHERS, Mary. 1990. The book of memory. Cambridge: Cambridge University Press.

CESARINO, Pedro. 2003. Palavras torcidasmetáfora e personificação nos cantos xamanísticos ameríndios. Dissertação de Mestrado, Programa de PósGraduação em Antropologia Social, Museu Nacional-UFRJ.

- 2010. "Donos e duplos: propriedade e replicação entre os Marubo". Revista de Antropologia, 53:147-199.

- 2011a. Oniska - Poética do xamanismo na Amazônia. São Paulo: Editora Perspectiva.

. 2011b. "Entre la parole et l'image. Le système mythopoétique marubo". Journal de la Société des Américanistes, 97(1):223-259. 2011c. "Le problème de la duplication et de la projection visuelle chez les Marubo (Amazonie occidentale)". Images Re-vues, 8:1-14.

- 2012. "A escrita e os corpos desenhados: transformações do conhecimento xamanístico entre os Marubo". Revista de Antropologia, 55(1):75-139.

- 2013. Quando a terra deixou de falarcantos da mitologia marubo. São Paulo: Ed. 34.

. 2014. "Multiple biographies - shamanism and personhood among the Marubo of Western Amazonia". In: S. Oakdale $\&$ M. Course (eds.), Fluent selves - autobiography, person and history in Lowland South America. Lincoln: University of Nebraska Press [no prelo].

COSTA, Luiz Antonio. 2007. As faces do jaguar. Parentesco, história e mitologia entre os Kanamari da Amazônia Ocidental. Tese de Doutorado, Museu Nacional, PPGAS-UFRJ.

DÉLÉAGE, Pierre. 2011. “Les pictographies narratives amérindiennes". In: C. Jacob (ed.), Les mains de l'intellect, lieux de savoir 2. Paris: Albin Michel. pp. 744764.

. 2009. La croix et les hiéroglyphes. Paris: Musée du Quai Branly/ Éditions Rue D'Ulm.

. 2006. Lechamanismesharanahua (enquête sur l'apprentissage et l'épistemologie d'un rituel). Thèse de Doctorat, École des Hautes Études en Sciences Sociales.

DELEUZE, Gilles. 1988 [1968]. Diferença e repetição. Rio de Janeiro: Graal. . 1969. Logique du sens. Paris: Les Éditions de Minuit.

DELEUZE, Gilles \& GUATTARI, Félix. 1980. Mille plateaux. Paris: Les Éditions de Minuit. 
1991. Qu'est-ce que la philosophie? Paris: Les Éditions de Minuit.

FAUSTO, Carlos. 2008. "Donos demais: maestria e domínio na Amazônia". Mana. Estudos de Antropologia Social, 14(2):329-366.

FRANCHETTO, Bruna. 2007. "Les marques de la parole vraie en kuikuro, langue caribe du Haut-Xingu (Brésil)". In: Z. Guentchéva \& I. Landaburu (orgs.), L'énonciation médiatisée II. Le traitementépistémologique de l'information: illustrations amérindiennes et caucasiennes. Paris: Éditions Peeters. pp. 173-204.

GARCILASO DE LA VEGA, Inca. 2005. Comentarios reales de los Incas. Ed. de Carlos Araníbar. México: Fondo de Cultura Económica.

GELL, Alfred. 1998. Art and agency. Oxford: Oxford University Press.

GOODY, Jack. 1994 [1993]. Entre l'oralité et l'écriture. Paris: P.U.F.

HUGH-JONES, Stephen. 1994. "Shamans, prophets, priests and pastors". In: C. Humphrey \& N. Thomas (eds.), Shamanism, history and the State. Ann Arbor: University of Michigan Press. pp. 32-75.

KATUKINA, Benjamin André \& SENA, Vera Olinda. s/d. Mito katukina (Noke Shoviti). Rio Branco: Editora Poronga.

KENSINGER, Kenneth. 1995. How real people ought to live. Illinois: Waveland Press.

KIRBY, John. 1997. "Aristotle on metaphor". The American Journal of Philology, 118(4):517-554.

LÉVI, Pierre. 1996. O que é o virtual? São Paulo: Ed. 34.

LÉVI-STRAUSS, Claude. 1964. Le cru et le cuit. Paris: Plon.

LIMA, Tânia Stolze. 1996. “O dois e seu múltiplo: reflexões sobre o perspectivismo em uma cosmologia tupi". Mana. Estudos de Antropologia Social, 2(2):21-49.
- 2005. Um peixe olhou para mim (o povo Yudjá e a perspectiva). São Paulo: Editora Unesp/ NuTI.

LORD, Albert. 1965. The singer of tales. Nova York: Atheneum.

LUCIANI, José Antonio Kelly. 2001. "Fractalidade e troca de perspectivas". Mana. Estudos de Antropologia Social, 7(2):95-132.

MELATTI, Julio Cezar. 1977. “Estrutura social marubo: um sistema australiano na Amazônia". Anuário Antropológico, 76:83-120.

MITCHELL, W. J. T. 1986. Iconology (image, text, ideology). Chicago: The University of Chicago Press.

MONTAGNER, Delvair. 1996. A morada das almas. Belém: Museu Paraense Emílio Goeldi.

MUNN, Nancy. 1986 [1973]. Walbiri Iconography. Chicago: The University of Chicago Press.

NAGLER. Michael. 1967. "Towards a generative view of the oral formula". Transactions and Proceedings of the American Philological Association, 98:269-311.

NAVEIRA, Miguel Carid. 2007. Yama yama: os sons da memória. Tese de Doutorado, Programa de Pós-Graduação em Antropologia Social, Universidade Federal de Santa Catarina.

NOLL, Richard. 1985. "Mental imagery as a cultural phenomenon: the role of visions in Shamanism". Current Anthropology, 26(4):443-461.

PITARCH, Pedro. 2000. "Conjeturas sobre la identidad de los santos tzeltales". Journal de la Société des Américanistes, 86(1):129-148.

RIBEIRO, Berta. 1992. "A mitologia pictórica dos Desâna". In: L. Vidal (org.), Grafismo indígena. São Paulo: Studio Nobel/ Fapesp/ Edusp. pp. 35-42.

RICOEUR, Paul. 1975. La métaphore vive. Paris: Seuil. 
SEKAQUAPTEWA, Emory \& WASHBURN, Dorothy. 2004. "They go along singing: reconstructing the Hopi past from ritual metaphors in song and image". American Antiquity, 69(3):457-486.

SEVERI, Carlo. 2007. Le principe de la chimère. Paris: Musée du Quai Branly/ Éditions Rue D'Ulm.

SILVA, Márcio. 1998. "Tempo e espaço entre os Enawenê-Nawê". Revista de Antropologia, 41(2):21-52.

STRATHERN, Marilyn. 1988. The gender of the gift. Berkeley: University of California Press.

TOWNSLEY, Graham. 1993. "Song paths: the ways and means of Yaminawa shamanic knowledge". L'Homme, 126-128:449-468.

URTON, Gary. 1998. "From knots to narratives: reconstructing the art of historical record keeping in the Andes from Spanish transcriptions of the Inca khipus". Ethnohistory, 45(3):409-438.

VIVEIROS DE CASTRO, Eduardo. 1986. Araweté: os deuses canibais. Rio de Janeiro: Zahar/ Anpocs.

- 2002. A inconstância da alma selvagem. São Paulo: Cosac Naify.

_. 2002b. "O nativo relativo". Mana. Estudos de Antropologia Social, 8(1):113149.

. 2007. "Xamanismo transversal". In: R. Caixeta de Queiroz \& R. Freire Nobre (orgs.), Lévi-Strauss: leituras brasileiras. Belo Horizonte: Editora da UFMG. pp. 79-125.

WAGNER, Roy. 1975. The invention of culture. Chicago: The University of Chicago Press.

WERLANG, Guilherme. 2001. Emerging peoples: Marubo myth-chants. Phd Thesis, University of Saint Andrews. YATES, Frances. 2000 [1966]. The art of memory. London: Pimlico. 


\section{Resumo}

Este artigo pretende explorar a relação entre as artes verbais dos Marubo (falantes de pano da Amazônia ocidental) e um repertório de desenhos elaborados por xamãs. Esquemas cosmográficos visuais, os desenhos possuem afinidades com outras tecnologias ameríndias da memória, também marcadas pelo trânsito entre expressões verbais e gráficas. Realizado a pedido do antropólogo, tal repertório de imagens atualiza no suporte gráfico uma composição formular, paralelística e metafórica altamente padronizada. A análise das composições visuais é conduzida em paralelo com o estudo das fórmulas poéticas xamanísticas, levando em conta os problemas da memória, da transmissão, da aprendizagem e da aquisição do conhecimento especializado. $\mathrm{O}$ estudo da interface entre imagens e artes verbais se articula a elementos da cosmologia, das noções de pessoa e do pensamento xamanístico marubo.

Palavras-chave Xamanismo, Cosmologia, Iconografia, Artes verbais.

\section{Abstract}

This article explores the relation between the verbal arts of the Marubo (Panoan speakers of western Amazonia) and a repertoire of drawings made by their shamans. These drawings are visual cosmographic schemes, possessing affinities with other Amerindian technologies of memory that are also marked by the transit between verbal and graphic expressions. Produced for the anthropologist, the repertoire of images actualizes, in a graphic medium, a formulaic, parallelistic and metaphoric composition that is highly patterned. The analysis of the visual compositions is carried out in parallel with the study of poetic, shamanistic formulas, taking into account questions concerning memory, transmission, and the acquisition of specialized knowledge. The study of the interface between images and verbal arts is articulated with elements of cosmology, concepts of the person and Marubo shamanistic thought.

Key words Shamanism, Cosmology, Iconography, Verbal arts. 